\title{
Środa i jej święto w tradycji religijnej Jezydów ${ }^{1}$
}

\author{
Artur Rodziewicz iD https://orcid.org/0000-0002-5907-3664 \\ Zakład Iranistyki \\ Uniwersytet Jagielloński \\ e-mail: artur.rodziewicz@uj.edu.pl
}

\section{Abstract \\ Wednesday and its Festival in the Religious Tradition of the Yezidis}

The paper is devoted to the holy day of the Yezidis, Wednesday, and the Spring festival of Çarşemiya Sor. I propose an interpretation of the meaning of this day, pointing to the supposed relationship between the meaning of Wednesday and the description of 'fourth day' in the Old Testament tradition. I also show that the annual feast of Çarşemiya Sor, just like every Wednesday of the week, for the Yezidis commemorate the creation of the material world and subjecting it to the power of angels (especially to the Peacock Angel) and heavenly bodies. I rely mainly on the Yezidi sources and materials gathered during my own field research in Iraq and the South Caucasus.

Keywords: festivals, Wednesday, Spring festival, Yezidis, cosmogony, Peacock Angel, angels, Sun, Moon, stars, Spring rituals, Torah, Genesis

Słowa kluczowe: święta środa, Jezydzi, kosmogonia, Anioł Paw, anioły, słońce, księżyc, gwiazdy, obrzędy wiosenne, Tora, Księga Rodzaju

W odróżnieniu od żydów, chrześcijan i muzułmanów, którzy za dni świąteczne uznają sobotę, niedzielę i piątek, Jezydzi² szczególne znaczenie przypisują środzie.

${ }^{1}$ Artykuł powstał w wyniku badań realizowanych w ramach stażu finansowanego ze środków Narodowego Centrum Nauki (2016/20/S/HS1/00055). Dziękuję Panu Profesorowi Bogdanowi Składankowi za lekturę pierwotnej wersji tego tekstu i życzliwe uwagi.

${ }^{2}$ Słowo to zapisuję wielką literą, przychylam się bowiem do argumentacji na rzecz uznania Jezydów za osobny naród. Pisząc o Jezydach, jako o przedstawicielach jezydyzmu (bądź „Szarfadin”, jak sami nazywają swoją religię), także posługuję się wielką literą. Inaczej bowiem niż w przypadku innych grup dla Jezydów religia jest bezpośrednio powiązana z etnicznością (dlatego też obowiązuje ich ścisły zakaz egzogamii) - Jezydą trzeba się urodzić, a odrzucenie religii skutkuje tym, że społeczność jezydzka uznaje taką osobę za „martwą”. Zob. A. Rodziewicz, The Nation of the Sur: The Yezidi Identity between Modern and Ancient Myth, [w:] Rediscovering Kurdistan's Cultures and Identities: The Call of The Cricket, J. Bocheńska (red.), Cham 2018, s. 259-326; idem, Milete min Êzîd. The Uniqueness of the Yezidi 
Przejawia się to zarówno w ustanowieniu jej „dniem świętym”, jak i w celebrowaniu w wiosenną środę święta Çarşemiya Sor, ${ }^{3}$ połączonego z obchodami Nowego Roku. Zazwyczaj obranie przez Jezydów akurat tego dnia tygodnia tłumaczy się ich chęcią odróżnienia się od wyznawców pozostałych religii. W niniejszym artykule proponuję jednak inne wyjaśnienie, w którym wydobywam metafizyczne znaczenie środy. Kontynuuję i zarazem rozwijam tu wątek, który podjąłem wcześniej w studium jezydzkiego święta Çarşemiya Sor ${ }^{4}$.

\section{1. Środa}

Zgodnie z tradycją znaną też innym kulturom dla Jezydów dzień kończy się wraz zachodem słońca, kiedy to rozpoczyna się dzień kolejny. Toteż na środowe modlitwy Jezydzi gromadzą się - jeśli spojrzeć na to z naszej perspektywy - we wtorek wieczorem. Tak charakteryzuje specyfikę tego szczególnego dnia jezydzki duchowny Pir Dima:

Zgodnie z jezydzką tradycją, kiedy zaczyna zachodzić słońce, nadchodzi następny dzień. Tak więc we wtorkowy wieczór, gdy tylko słońce zajdzie, rozpoczyna się środa. W świątyniach zaczyna się modlitwa, zapala się lampy olejne, tzw. çira, pachną wonności - nazywamy je bkhur - i przeprowadza się obrzęd. Kiedy nadejdzie środa, nie należy się kąpać, golić, robić prania, szyć, małżonkowie nie powinni dzielić ze sobą łoża - a to wszystko z powodu świętości środy. Z kolei w środę wieczorem zaczyna się czwartek ${ }^{5}$.

Wyznaczenie dni, tygodni, miesięcy i lat wiąże się z pozycją słońca i księżyca. Wedle nich ustala się także, kiedy przypadają uroczystości religijne. W odróżnieniu od judaizmu i chrześcijaństwa w religii jezydzkiej są one zarazem obiektem kultu. Każdy Jezyda zobowiązany jest do codziennej modlitwy o świtaniu, kiedy całuje pierwsze promienie wschodzącego słońca dotykające ziemi i zwraca się ku niemu twarzą. Modli się także podczas zachodu słońca.

Jezydzi posiadają własne nazwy miesięcy, miarę lat oraz cyklów czasu. Ich święta podzielić można na dwa rodzaje: te, których wyznaczeniu służy kalendarz księżycowy, oraz te, które ustala się z wykorzystaniem kalendarza słonecznego, jak to się dzieje w przypadku święta Nowego Roku (Serê Sal), który rozpoczyna się wiosną, w środę. Tego samego dnia obchodzone jest też święto Çarşemiya Sor. Najprościej byłoby zatem uznać, że także wybór środy jako najświętszego dnia tygodnia jest prostą konsekwencją uznania jej za początek nowego cyklu, a więc za dzień pierwszy. Jakkolwiek rodzi to kolejne pytanie: dlaczego to właśnie środa miałaby być dniem

Concept of the Nation, „Securitologia” 2018, nr 1, s. 67-78; E. Spät, Shahid bin Jarr, Forefather of the Yezidis and the Gnostic Seed of Seth, „Iran and the Caucasus” 2002, nr. 6, s. 27-56.

${ }^{3}$ Wyrazy obcojęzyczne zapisuję alfabetem kurdyjskim, cyrylicą bądź uproszczoną transkrypcją fonetyczną.

${ }^{4}$ A. Rodziewicz, And the Pearl Became an Egg: The Yezidi Red Wednesday and Its Cosmogonic Background, „Iran and the Caucasus” 2016, nr 20, s. 347-367.

${ }^{5}$ Idem, Odrodzenie religii jezydzkiej w Gruzji? Rozmowy z Dimitrijem Pirbarim, głowa Duchowej Rady Jezydów w Gruzji, „Fritillaria Kurdica” 2017, nr 16, s. 34. 
początkowym? Wedle jezydzkiej tradycji przekazywanej w religijnych pieśniach kreacja świata miała rozpocząć się w sobotę bądź w niedzielę. Środa, zgodnie z tą kalkulacją, jest dniem czwartym lub piątym, ale z pewnością nie pierwszym; na dodatek w pewnym sensie zaczyna się we wtorek, czyli dnia trzeciego lub czwartego.

Informacje na temat tradycyjnej numeracji dni tygodnia dostarczają przede wszystkim jezydzkie hymny (kełle). W jednym z najważniejszych, w Qewlê Zebûnî Meksûr, opiewającym kreację świata przez „Pana i Władcę” (Padşa), stwierdza się, że:

Şemîyê danî esase,

Li înîye kir xilase.
Fundament położył dnia sobotniego

W piątek ukończył [swoje dzieło] ${ }^{6}$.

Jednakże na przykład Hymn o miesiącach (Qewlê Meha) sugeruje już inną numerację:

Ewî afirandibû dûşembî. [...]

Ewî sêsembû dikire sê ye. [...]

Ewî çarşembû dikire çare?
On stworzyt poniedziatek. [...]

On uczynit wtorek dniem trzecim. [...]

On uczynit środę dniem czwartym.

Należy tu dodać, że sprawę dodatkowo komplikuje język, którego używają Jezydzi w swoich hymnach, bowiem nazwa 'środa' (çarşem/çarşemb/çarşembî) z góry określa jej numerację - rozpoczynającą się od soboty (şemî, şembî), i wiąże się z liczebnikiem cztery (çar).

Zgodnie z treścią hymnów kreację świata poprzedzał szczególny statyczny stan, podczas którego Bóg znajdował się w Perle stworzonej ze swej Tajemnicy/Istoty. Po jej rozbiciu pojawiło się światło i wylał się z niej Ocean zawierający cztery elementy świata, które następnie zostały zebrane przy udziale świetlistej Miłości. Powstaniu każdego z dni tygodnia, których jest siedem, miała towarzyszyć kreacja jednego z Bożych aniołów, zwanych też Siedmioma Tajemnicami. Każdemu z nich podlegała jedna $\mathrm{z}$ form niebios, każdy jest też panem określonego cyklu czasu. Wątek ten obecny jest także w jezydzkim apokryfie Meszefa Resz:

Pierwszego dnia, w niedzielę, stworzył Anioła Azazila, i to jest Anioł Paw, przywódca wszystkich. W poniedziałek stworzył Anioła Dardaila, i to jest Szejch Hasan. We wtorek stworzył Anioła Israfila, i to jest Szejch Szams. W środę stworzył Anioła Michaela, i to jest Szejch Abu Bakr. W czwartek stworzył Anioła Azraila, i to jest Sadżad al-Din. W piątek stworzył Anioła Szemnaila, i to jest Nasr al-Din. W sobotę stworzył Anioła Nuraila, i to jest Jadin [Fakhr al-Din]. I uczynił Anioła Pawia przywódcą nad wszystkimi. Po czym stworzył formę siedmiu niebios, ziemi, słońca i księżyca ${ }^{8}$.

${ }^{6}$ W. 35: A. Rodziewicz, Jezydzkie hymny kosmogoniczne: „Hymn o Nieszczęsnym Rozbitku” (Qewlê Zebûnî Meksûr) i „,Hymn o Be i A” (Qewlê Bê û Elîf), „Przegląd Orientalistyczny” 2018, nr 265-266, s. 215. Por. Qewlê Şêx û Aqûb, w. 18-19. O. Celîl, C. Celîl, Zargotina K'urda, Kurdskij fol'klor, t. 2, Moskwa 1978, s. 45. Jeżeli nie zaznaczono inaczej, wszystkie cytaty z języków obcych w przekładzie autora artykułu.

7 Tekst kurmandżi: Kh. Omarkhali, K. Rezania, Some Reflections on Concepts of Time in Yezidism, [w:] From Daēnā to Dîn: Religion, Kultur und Sprache in der iranischen Welt, Ch. Allison, A. Joisten-Pruschke, A. Wendtland (red.), Wiesbaden 2009, s. 341-342.

${ }^{8}$ I. Joseph, Yezidi Texts, „American Journal of Semitic Languages and Literatures” 1909, nr 25, s. $122-123$. 
Zestawienie tych fragmentów pokazuje, że za dzień pierwszy raz uznaje się niedzielę, a raz sobotę. Konsekwentnie, środa powinna być dniem czwartym bądź piątym. Jeśli więc założyć, że powyższe cytaty przedstawiają wiarygodną relację na temat odliczania dni tygodnia przez Jezydów, to chcąc uniknąc sprzeczności, trzeba by albo założyć, że pochodzą z różnych okresów, pomiędzy którymi bądź ta numeracja czy terminy określające nazwy tygodnia uległy zmianie, bądź też zmieniało się postrzeganie początku dnia. Innym rozwiązaniem byłoby uznanie 'soboty' (şemî) za dzień zerowy, w którym Bóg, tworząc podstawę czy fundament, przygotowuje się do kreacji rozpoczętej w sobotni wieczór, a więc wraz z rozpoczęciem się niedzieli. Wówczas środa byłaby dniem czwartym. Jezydzcy znawcy religijnej tradycji, kełłalowie, z którymi miałem okazję rozmawiać (podczas prac nad polskim przekładem hymnów religijnych) w irackich miejscowościach Baszike i Bahzani, potwierdzali taką właśnie numerację tego szczególnego dla nich dnia.

\section{2. Święto Środy}

Pierwsze ze świąt w jezydzkim kalendarzu to święto Serê Salê (Nowy Rok, dosłownie: Początek Roku), obchodzone w środę nazywaną Çarşemiya Sor. Określenie to można przetłumaczyć jako Czerwona Środa bądź Środowe Święto, co wynika z dwuznaczności słowa sor (pahlawijskie sur, suri), które w dialekcie kurmandżi (podobnie jak w tekstach zoroastryjskich) oznaczać może zarówno „czerwień”, jak i „święto”. Trudno ostatecznie zawyrokować, które tłumaczenie jest w tym przypadku właściwsze, sami bowiem Jezydzi wskazują na oba z nich.

Za pierwszym przemawia związek tego święta z kolorami, co podkreśla się między innymi w wersach śpiewanego wówczas Hymnu Środy (Qewlê Çarşemê):

Hat çarşema sore,

Nîsan xemilandibû bi xore,

Ji batin da ye bi more.

Hat çarşema sor $\hat{u}$ zere,

Bihar xemilandibû ji kesk $\hat{u}$ sor û sipî û zere,

Me pê xemilandin seredere.
Przyszło święto Środy/Czerwona Środa

Nisan przystroił się słońcem,

W ukryciu uświęcony.

Przyszła środa czerwona i żółta,

Przystroiła się wiosna z zieleni i czerwieni, bieli i żółci

I ozdobiliśmy nimi nadproża naszych drzwi.

Jezydyzm przypisuje kolorom szczególną symbolikę, która nie została jednak dotąd wyczerpująco opisana ${ }^{10}$. W literaturze tematu spotyka się zaledwie pojedyncze wzmianki o kolorze czarnym, który jest kolorem jezydzkich fakirów, oraz

9 A. Dehxodā, Loghatnāmeh, M. Mo'in, J. Shahidi (red.), t. 8, Tehran 1993-1994. s. 12197. Por. M. Kasheff, A.A. Sa 'īdī Sīrjānī, Čahāršanba-sūrī, [w:] Encyclopcedia Iranica, E. Yar-Shater (red.), t. IV, fasc. 6, London 1990, s. 630-634.

${ }^{10}$ Niedawno ukazała się broszura Hussaina Zedo (Hisên Zêdo) Wate $\hat{u}$ Sembolîya Rengan di Ézidîtîyê [Znaczenie i symbolika kolorów w jezydyzmie], Qamişlo 2017, jest jednak pobieżna i zawiera wiele merytorycznych błędów. 
ciemnoniebieskim, z którym wiąże się jezydzkie tabu. Symbolika kolorów odgrywa istotną rolę na przykład podczas czwartego dnia jesiennego święta Cejna Cimayê, kiedy to przeprowadza się rytuał Parî Suwar Kirin polegający na „chrzczeniu” w świętym Białym Źródle (Kaniya Spî) kolorowych chust z sanktuariów jezydzkich świętych i aniołów.

Podkreślanie czerwieni w kontekście święta Środy wiązałoby się niewątpliwie z tym, że podczas odbywających się wówczas obrzędów znaczną rolę odgrywają barwy związane z wiosennym początkiem roku, co manifestuje się, kolorując na tę okoliczność jajka. Stałym elementem święta są też czerwone kwiaty, zwane Gulilkan Nîsane, którymi Jezydzi przystrajają ubrania, włosy i nadproża swych domostw ${ }^{11}$. Czerwień to również kolor przypisywany ogniowi, który jest jednym z najważniejszych elementów elementem rytuałów rozpoczynających święto.

Warto zwrócić uwagę, że Çarşemiya Sor poprzedza obchodzone między innymi przez Jezydów zamieszkujących Turcję święto Czarnej Środy (Çarşema Reş) $)^{12}$, pierwszej w marcu. Z kolei, także w marcu, Jezydzi zamieszkujący Gruzję i Armenię świętują jeszcze Święto Noworocznego Kulicza (Kuloça Serê Salê) ${ }^{13}$. Jak pisze Dimitrij Pirbari,

[...] Jezydzi odliczają trzy święte środy i nazywają je: Oxrçarşam, Axrçarşam i Karaçarşam. Te trzy święte środy pokrywają się ze staroirańskimi. Jeśli Karaçarşam u Jezydów zamieszkujących tereny dawnego Związku Radzieckiego przypada na marzec, to u pozostałych Jezydów - na kwiecień. U Jezydów z terenów Związku Radzieckiego, uchodźców z regionu Sarhadu (Van, Kars, Igdir, Musz, Bajazyd), święto Çarşama Sor nie było znane, ale jego elementy zachowały się i scaliły ze świętem Kuloça Serê Salêt ${ }^{14}$.

Za drugim tłumaczeniem - Święto Środy/Środowe Święto - przemawia argument, że święto to dotyczy szczególnej, noworocznej środy, która w owym „czasie świętym" staje się środą par excellence, i tak jak co tydzień Jezydzi celebrują środę jako najważniejszy dzień w tygodniu, tak owa środa w miesiącu nisan staje się najważniejszą środą w roku. Niektórzy Jezydzi wolą to tłumaczenie także z tego względu, że pozwala ono na dodatkowe podkreślenie oryginalności ich święta i odcięcie się od skojarzeń z kurdyjskim i irańskim Czaharszanbe-je Suri. Zwolennicy takiego podejścia twierdzą też, że istotnie Jezydzi czcili Nowy Rok w środę, więc nazywano

11 Por. G.L. Bell, Amurath to Amurath, London 1911, s. 275. Próbowano dostrzegać w tym zwyczaju pozostałość rytuałów poświęconych Tammuzowi. H. Frankfort, A Tammuz Ritual in Kurdistan (?), „Iraq” 1934, nr 1, s. 144-145.

12 Zob. L. Turgut, Ancient Rites and Old Religions in Kurdistan, Erfurt 2013.

13 D. Pirbari, Jezidskij prazdnik „Klocza sare sale”, „Nowyj Wzgljad” 2012, nr 7, s. 7; E.S. Drower, Peacock Angel: Being Some Account of Votaries of a Secret Cult and Their Sanctuaries, London 1941, s. 112. Por. M.B. Rudenko, Novogodnie obrjadovyje prazdniestwa u kurdow, [w:] Fol'klor i etngtafija. Obrjady i obrjadowyj fol'klor, B.N. Putiłow (red.), Lieningrad 1974, s. 119; T.F. Aristowa, Kurdy Zakawkazja (istoriko-etnograficzieskij oczierk), Moskwa 1966, s. 170, 174-175. O podobnym obyczaju zamieszkujących okolice Mardinu „Czcicieli Słońca” wspominał Horatio Southgate. Zob. idem, Narrative of a Tour through Armenia, Kurdistan, Persia, and Mesopotamia, t. 2, New York 1840, s. $284-285$.

14 Pir Dima, Nowyj god u jezidow, www.ezidipress.com/ru/2014/04/15/чаршама-сарсале/ [dostęp: 29.11.2019]. 
ten dzień Noworoczną Środą, lecz nazwa Çarşemiya Sor jest zapożyczeniem i nie była dawniej w użyciu:

Termin ten wcześniej nie był używany. Wcześniej było Aida Serê Salê lub Çarşema Serê Salê, czy Aida Serê Nisane. Sor pojawiło się pod wpływem ideologów PKK ${ }^{15}$, którzy bardziej powiązali to święto z irańskim. To święto Tawusi Malaka. U nas nazywało się Aida Şêx Alê Şemsa. Mamy święto przypominające Nowy Rok - Kuloça Serê Salê - przypadające w marcu, kiedy pieczemy słodki chleb - kuloç - z wisienką w środku. Podobne święto mają Jezydzi w Iraku, w styczniu, nazywa się Bêlinde ${ }^{16}$.

Nie należy moim zdaniem negować związków jezydzkiego święta Çarşemiya Sor z irańskim świętem Czaharszanbe-je Suri, co chętnie czynią Jezydzi, chcąc podkreślić swoją oryginalność. Przy świadomości oczywistych różnic identyczna treść ich nazw oraz niektórych elementów nie wygląda na przypadek, ale może świadczyć o genetycznym związku obu tych świąt. Za Samanidów, podobnie jak w jezydzkie święto, wieczorem w dniu poprzedzającym koniec roku, zwanym Szab-e Suri, rozpalano ognie. Dzisiejsi Irańczycy i Kurdowie świętują Czaharszanbe-je Suri w miesiącu Farwardin, w ostatnią środę roku przed Nowym Rokiem (Newroz) ${ }^{17}$. Po zachodzie słońca rozpalają ogniska, a skacząc przez nie, wołają: „Moja żółć - z tobą, twoja czerwień - ze mną" (Zardi-e man az to, sorchi-e to az man) ${ }^{18}$, co jest symbolicznym aktem unicestwienia w ogniu tego, co negatywne, oraz nabycia tego, co pozytywne, wyrażonym za pomocą ognistej czerwieni. W Iranie święto to zastąpiło dawne Farvardegān (wcześniejsze Hamaspathmaedaya) ${ }^{19}$, podczas którego wspominano zmarłych i oddawano cześć ich duszom. Na temat starego irańskiego święta Nowego Roku tak pisał Biruni w słynnym dziele O pozostałościach minionych stuleci:

Szóstego dnia miesiąca Farwardin [...] obchodzi się Wielki Newroz, święto o wielkim znaczeniu dla Persów. Tego dnia - ich zdaniem - Bóg zakończył stwarzanie ${ }^{20}$.

Dla ludów irańskich zatem środowe święto, choć nie pokrywa się z Nowym Rokiem (Newroz), to jednak jest z nim skorelowane i bliskie w czasie. To, że terminy jezydzkiego i irańskiego święta się nie pokrywają, wynika nie tyle z ich odmienności,

${ }^{15}$ Partia Pracujących Kurdystanu (Partiya Karkerên Kurdistanê).

${ }^{16}$ A. Rodziewicz, Odrodzenie religii jezydzkiej w Gruzji?, op. cit., s. 33-34.

${ }_{17}$ Zob. opis tego święta w XVII-wiecznym kurdyjskim poemacie Ahmeda Chaniego Mem $\hat{u}$ Zîn (w. 480-515: Axmed Xani, Mem û Zîn. Kriticeskiy tekst, perevod, predislovie i ukazateli M.B. Rudenko, Moskva 1962, s. 00_or).

${ }_{18}$ Por. M. Mokri, Les rites magiques dans les fêtes du „Dernier Mercredi de l'Année” en Iran, [w:] Mélanges d'orientalisme offerts à Henri Massé, Téhéran 1963, s. 289.

${ }_{19}$ Por. M. Boyce, On the Calendar of Zoroastrian Feasts, „Bulletin of the School of Oriental and African Studies" 1970, nr 33, s. 518-519; eadem, A Persian Stronghold of Zoroastrianism, Oxford 1977, s. 212-213; eadem, Further on the Calendar of Zoroastrian Feasts, „Iran” 2005, nr 43, s. 1-38; eadem, A History of Zoroastrianism, t. 1, Leiden 1975, s. 172-173.

${ }^{20}$ Al-Biruni, The Chronology of Ancient Nations, London 1879, s. 201; idem, Chronologie orientalischer Völker von Albērūnī, Leipzig 1878. Por. A. Krasnowolska, Some Key Figures of Iranian Calendar Mythology (Winter and Spring), Kraków 1998, s. 67; H. Massé, Croyances et coutumes persanes, Paris 1938, s. 148-159. Zob. też rozdz. The „Ede y Nu Rooz”, [w:] G. Fowler, Three Years in Persia: With Travelling Adventures in Koordistan, t. 1, London 1841, s. 297-314. 
ile ze zmieniania się kalendarzy w dawnym Iranie. Należy odnotować, iż także niektórzy Jezydzi utrzymują, że i oni celebrowali wcześniej oba swoje święta osobno:

Nasz Nowy Rok jest starszy od Szejcha Adiego. To święty dzień. Nie musi być w środę. Po raz pierwszy był świętowany w środę, kiedy ten dzień zbiegł się z Nowym Rokiem i tak już zostało. [...] To święto na cześć Tawusi Meleka² ${ }^{21}$.

Z powyższych słów, stojących cokolwiek w sprzeczności z innymi wypowiedziami Jezydów, mogłoby wynikać, że święta te nie są z sobą z konieczności powiązane. Wypadałoby zatem zapytać, kiedy te święta zbiegły się po raz pierwszy oraz dlaczego „tak już zostało”, dlaczego Jezydzi je łączą. Zgodnie z logiką można przypuszczać, że święta niemające ze sobą związku nie występują dokładnie tego samego dnia, a gdyby już miało się tak zdarzyć, to byłby to przypadek jednostkowy, który nie przeszedłby w obyczaj powtarzany rokrocznie.

\section{Relacje na temat święta Çarşemiya Sor}

Literatura na temat środowego święta Jezydów jest bardzo uboga. Jeśli nie liczyć zapisu wykładu Ethel Drower pt. The Peacock Angel in the Spring ${ }^{22}$ oraz kilku jezydzkich artykułów w lokalnych czasopismach, publikacje na temat Çarşemiya Sor ograniczają się zasadniczo do pobieżnych napomknień w relacjach z podróży misjonarzy i orientalistów oraz w monografiach naukowych poświęconych Jezydom ${ }^{23}$. Szczególny przypadek stanowi obszerny syriacki tekst na temat Jezydów, sporządzony w 1874 r. przez żyjącego wśród Jezydów chaldejskiego (katolickiego) mnicha, Izaaka z Bartelli, w którym kilka stron poświęcono świętu Serê Salê. Notabene w tekście tym poświadczone jest świętowanie Nowego Roku właśnie w środę ${ }^{24}$.

Jeden z takich pierwszych opisów sporządził George Percy Badger, który w 1850 r. odwiedził Baszike i Bahzani. W notatce z 18 kwietnia zapisał:

Tego dnia, będącego dla Jezydów dniem noworocznym, chodziliśmy znów po wioskach, aby być świadkami ich świąt, oraz obserwowaliśmy wiele dzikich szkarłatnych anemonów zatkniętych nad wejściem do poszczególnych domów. Po zapytaniu, dowiedzieliśmy się, że miało to

${ }^{21}$ Fragment wywiadu z jezydzką starszyzną. J.S. Guest, Survival among the Kurds: A History of the Yezidis, London-New York 1993, s. 227.

22 E.S. Drower, The Peacock Angel in the Spring, „Journal of the Royal Central Asian Society” 1940, nr 27, s. 391-403.

${ }^{23}$ C. Brockelmann, Das Neujahrsfest der Jezîdîs, „Zeitschrift der Deutschen Morgenländischen Gesellschaft" 1901, nr 55, s. 388-390; I. Joseph, Devil Worship: The Sacred Books and Traditions of the Yezidiz, Boston 1919, s. 174-176; L. Krajewski, Le culte de Satan: Les Yezidis, „Mercure de France” 1932, nr 826, s. 114-115; G. Furlani, Le Feste dei Yezidi, „Wiener Zeitschrift für die Kunde des Morgenlandes" 1938, nr 45, s. 52-58; M.B. Rudenko, Novogodnie obrjadovyje prazdniestwa u kurdow, op. cit., s. $118-124$.

${ }^{24}$ Zaznacza się też, że gdyby początek roku wypadał na piątek, to przenosi się go na środę: „Il Sarsale cade nel primo mercoledì del venerable Nisan (Aprile), e nel caso che cadesse nel primo venerdì, si transporta la festa al mercoledì seguente" [Izaak z Bartelli], Monte Singar: Storia di un popolo ignoto. Edited and Translated by Samuele Giamil, Rome 1900, s. 37. 
na celu przebłaganie Złej Zasady oraz zapobiegnięcie nieszczęściom w nadchodzącym roku. Praktyka ta przypomniała mi od razu pokropione krwią drzwi wejściowe Izraelitów w Egipcie jako znaku, aby ominął je anioł niszczyciel, i przywiodła mi także na myśl zwyczaj panujący wśród Hindusów i Parsów w Indiach, którzy na początku każdego Nowego Roku rozwieszają sznur liści u wejścia do swych domostw. Po powrocie do domu złożyło nam wizytę pięciu kełłalów, którzy przynieśli ze sobą swoje flety i tamburyny i zabawiali nas tym, co nazywali swoją świętą muzyką ${ }^{25}$.

Inna wczesna wzmianka pochodzi od Jurija Karcowa, rosyjskiego wicekonsula w Mosulu:

Szczególnie uroczyście świętuje się 4 kwietnia Nowy Rok. W noc przed Nowym Rokiem przynosi się na ofiarę jagnięta i kury. Młodzież idzie w pole, zbiera czerwone kwiaty i ozdabia nimi drzwi domów. Cztery godziny po zachodzie słońca rozpoczyna się uczta. Kełłalowie wykonują swoje arie. Tego dnia Bóg na niebie powierza nowy rok któremuś z meleków [aniołów-A.R.] ${ }^{26}$.

Sami Jezydzi o swoim święcie śpiewają w hymnach, ponadto opis jego poszczególnych elementów (wyglądający na interpolację) poświadczony jest też w arabskiej wersji apokryficznego Czarnego Pisma (Meszefa Resz). Rozpoczyna się on od uwagi: „Nasz nowy rok przypada na środę w pierwszym tygodniu miesiąca nisan. Nazywa się Sersali, czyli początek roku"'27.

Wspomina się tu także o przygotowywaniu świątecznych posiłków we wtorkowy poranek, składaniu w asyście śpiewających kełłalów ofiar na grobach zmarłych oraz zbieraniu przez dziewczęta czerwonych kwiatów, które posłużą o świcie dnia następnego do przyozdobienia wejść do domostw. Zaznacza się ponadto, że we wtorek nie należy wykonywać radosnej muzyki, tego bowiem dnia Bóg siedzi na tronie i wśród doradców przygotowuje dekrety na nadchodzący rok. Dopiero kiedy oświadczy, że zstąpi na ziemię, wszyscy powstają, radują się i zaczynają ucztować. Wówczas naznacza ich swoją pieczęcią i opieczętowany dokument przekazuje „bogu, który ma zstąpić" ${ }^{28}$. Inną wersję tej legendy zanotował Browski:

Nowy Rok to wielkie święto, które można zawsze oglądać w pierwszą środę po wiosennej równonocy. Tego dnia Bóg zbiera w raju wszystkich świętych i ich krewnych i sprzedaje nadchodzący rok na aukcji. Licytujący najwyżej zostaje uznany Rządcą roku i obejmuje kierownictwo nad ludzkimi losami zgodnie ze swą wolą, przydziela też obfitości i szczęścia, pragnienia i choroby. O poranku dnia poprzedniego koczek ${ }^{29}$ śle ze swego domu błagania do Meleka Tawusa, aby pobłogosławił wszystkim, do których dociera jego głos. Następnie młodzi udają się w góry i do lasu, aby zebrać czerwone kwiaty szkek, którymi ozdobią drzwi swych domów; żaden

${ }^{25}$ G.P. Badger, The Nestorians and their Rituals: With the Narrative of a Mission to Mesopotamia and Coordistan in 1842-1844, t. 1, London 1852, s. 119.

${ }^{26}$ J.S. Karciew [Karcow], Zamietki o turieckich jezidach, „Zapiski Kawkazkowo otdiela Imperatorskowo Russkowo Geograficzeskowo obszczestwa” 1891, t. 13, z. 2, s. 259.

${ }^{27}$ I. Joseph, Yezidi Texts, op. cit., s. 130.

${ }^{28}$ Idem, Yezidi Texts (Continued), „American Journal of Semitic Languages and Literatures” 1909, nr 3, s. 228. Por. O.H. Parry, Six Months in a Syrian Monastery, London 1895, s. 382-383; W.B. Heard, Notes on the Yezidis, „Journal of the Royal Anthropological Institute of Great Britain and Ireland” 1911, nr 41, s. 213; F. Nau Abbé, J. Tfinkdji, Recueil de textes et de documents sur les Yézidis, „Revue de L'Orient Chretien" 1915-1917, nr 10 (20), s. 259-262.

${ }^{29}$ Pomocnik świątynny, także rodzaj wieszczka. 
bowiem dom, który nie jest tak udekorowany, nie może być zabezpieczony przed nieszczęściami nadchodzącego roku ${ }^{30}$.

Słowa te wiążą się z wiarą Jezydów, że owego dnia kolejny z Bożych aniołów obejmuje cykliczną władzę nad światem, a zarazem jest to dzień upamiętniający jej archetypiczne przekazanie najpierwszemu z nich - Aniołowi Pawiowi ${ }^{31}$. Miało to nastąpić właśnie w mityczną środę, kiedy to ozdobił ziemię kolorami i dał jej życie.

O tym szczególnym święcie piszą dziś także Jezydzi w swoich podręcznikach do lekcji religii ${ }^{32}$, jak i w wydawanych przez siebie czasopismach $^{33}$. Jednakże publikowane tam artykuły mają bardzo różną wartość. Należy je czytać z wyjątkową ostrożnością, zazwyczaj bowiem stanowią mieszaninę cennych obserwacji z wynikami poszukiwania wiedzy o swojej religii w pracach zachodnich orientalistów z dołączeniem popularnych treści zaczerpniętych z internetu. Niemniej jednak nie można ich pominąć, ponieważ stanowią dokument współczesnego rozumienia elementów jezydzkiej religii przez członków tej społeczności. Opisy te są więc zarówno ważnym świadectwem prób skodyfikowania własnych obyczajów, spisania nieznanej szerzej tradycji ustnej, jak i jej twórczej modyfikacji. Widoczne są w nich także próby osadzenia jezydzkiego święta w historii regionu. Przykładem może być artykuł Środa $w$ mitologii jezydyzmu Alego Aliasa. Uznaje on środę za siódmy dzień tygodnia, a poświęcone jej święto wiąże z teorią Wielkiego Wybuchu ${ }^{34}$. O Święcie Środy pisał także w wydawanym w Duhoku piśmie „Lalish” Khalaf Salih:

Sarsal, albo jezydzki Nowy Rok, to święto, które zgodnie ze wschodnim kalendarzem przypada corocznie na pierwszą środę kwietnia. Święto to ma historyczne korzenie, które według jezydzkiej mitologii sięgają wstecz do początku stworzenia. Jest ono także nazywane świętem [...] Anioła Odnowiciela, którym jest Tawus Malak zstępujący na polecenie Boga z nieba na ziemię, aby odnowić życie na ziemi ${ }^{35}$.

W innym artykule, autorstwa Sabaha Darwesha, przytacza się następującą legendę:

Bóg poddał testowi swoich siedmiu aniołów. Azazel zdał egzamin i Bóg nazwał go Tawusem Malakiem i uczynił go królem aniołów. Bóg wysłał Tawusa Malaka, aby rozpuścił lód na ziemi, aby uczynić ją odpowiednią dla roślin, zwierząt i ludzkości, która na niej żyje. Wydarzenie to, zgodnie z jezydzkim kalendarzem, miało miejsce pierwszego kwietnia, który jest jezydzkim Nowym Rokiem. Zatem początek życia na ziemi jest początkiem religii Jezydów. Także kwiecień jest pierwszym miesiącem jezydzkiego kalendarza. $Z$ tego względu, że miało to miejsce

${ }^{30}$ L.E. Browski, The Yezidees, or Devil-Worshippers, „The Popular Science Monthly” 1889, nr 34, s. 481.

${ }^{31}$ Meszefa Resz: „Co tysiąc lat jeden z siedmiu bogów zstępuje, aby ustanowić rządy, ustawy i prawa, po czym powraca do swej siedziby" (I. Joseph, Yezidi Texts (Continued), op. cit., s. 225); Kiteba Dżilte: „Każdy wiek ma swego rządcę, który kieruje się moimi dekretami” (ibidem, s. 219).

32 Perwerda Êzidyatî. Rêza Şeşê Seretaŷ̀, Pîr Xidir Silêman (red.), Duhok 2712 [2013], s. 46-49; E. Akbaş, Êzdiyatî - 1 (waneyên olî ji bo zarokên êzdiyan), Bremen 2009, s. 63.

${ }^{33}$ Na przykład: D. Pirbari, Ajda Czarszama Sarsale, op. cit., s. 6; M. Heso, Çarşemba sor, „Kurdistan” 1998, nr 1; X.M., Cejna serê salê ya êzidîa (êzidîya), „Dengê Komkar” 1991, nr 131.

${ }^{34}$ A.Kh. Alias, Wednesday in Ezidism Mythology, „Silavgehalalish” 2010, nr 7, s. 2.

${ }^{35}$ Kh. Salih, , op. cit., s. 13. 
w środę, Jezydzi przełożyli ceremonię na ten dzień, jeśliby pierwszy kwietnia wypadał na któryś z innych dni ${ }^{36}$.

\section{Przebieg środowego święta Nowego Roku}

Główne obchody Çarşemiya Sor mają miejsce w irackiej dolinie Lalisz, w przypadającą po równonocy pierwszą środę miesiąca nisan (według kalendarza seleucydzkiego, tj. w trzecią środę kwietnia zgodnie z kalendarzem gregoriańskim). Zgodnie z jezydzką tradycją w miesiącu tym nie wolno zawierać małżeństw, co tłumaczy się tym, że jest to miesiąc, kiedy mogą się żenić aniołowie ${ }^{37}$. Nie należy także podejmować żadnej nowej działalności gospodarczej - czy to rolniczej, czy handlowej, budować domów ani zawierać umów. W pewnym sensie więc ów miesiąc, w którym celebruje się najważniejszą środę w roku, wiąże się z podobnymi zakazami, jakie dotyczą każdej środy w poszczególnym tygodniu.

Miesiąc nisan odgrywał szczególną rolę na Bliskim Wschodzie, co najmniej od epoki religii babilońskich ${ }^{38}$ do czasów judaizmu ${ }^{39}$ i chrześcijaństwa. Według średniowiecznych relacji także tzw. Sabejczycy z Harranu świętowali początek roku w tym miesiącu. Wówczas to mieli składać ofiary i oddawać cześć siedmiu planetarnym bóstwom ${ }^{40}$. W połowie tego samego miesiąca mieli także obchodzić święto na cześć Szamala $^{41}$, kojarzonego ze Słońcem i dżinami, ,połączone z ofiarami, kultem Słońca, ubojem ofiarnym, całopaleniem, jedzeniem i piciem"42. Święto, podobne do jezydzkiego, celebrowane jest też przez irackich mandajczyków, którzy wiążą je z upamiętnieniem duchów zmarłych oraz zwieńczeniem aktu kreacji świata ${ }^{43}$.

Zgodnie z jezydzką tradycją owej wiosennej środy zbiegają się aż trzy święta, ponieważ Çarşemiya Sor połączone jest z obchodami święta Nowego Roku (Serê $\mathrm{Sal}$ ), które jest jednocześnie świętem poświęconym Aniołowi Pawiowi, nazywanym

${ }^{36}$ S. Darwesh, The Ezidis New Year Feast (Sare Sal), „Slavgaha Lalish” 2009, s. 56.

${ }_{37}$ Por. Kh.F. Al-Jabiri, Stability and Social Change in Yezidi Society, nieopublikowana rozprawa doktorska, Oxford University 1981 [1982], s. 59.

${ }_{38}$ Por. J.B. Pritchard, Ancient Near Eastern Texts Relating to the Old Testament, Princeton 1969, s. 331-334.

${ }^{9}$ Por. A. Grant, The Nestorians: Or, the Lost Tribes, London 1841, s. 319-320.

${ }^{40}$ Al-Nadīm, The Fihrist (Kitāb al-Fihrist) B. Dodge (red. i thum.), New York 1970, s. 755-756. Zob. też J. Hjärpe, The Holy Year of the Harranians, „Orientalia Suecana” 1974-1975, nr 23-24, s. 68-83; H.J.W. Drijvers, Cults and Beliefs at Edessa, Leiden 1980, s. 58-60.

${ }^{41}$ Por. Al-Nadīm, op. cit., s. 918; Ş. Gündüz, The Knowledge of Life: The Origins and Early History of the Mandaeans and Their Relation to the Sabians of the Qur'an and to the Harranians, Oxford 1994, s. $151-152$.

42 Al-Nadīm, op. cit., p. 757.

${ }^{43}$ Obecnie Nowy Rok (Dihba Rba/Nauruz Rba) świętowany jest przez nich w sierpniu, jakkolwiek przypuszcza się, że pierwotnie obchodzono go w kwietniu. Wiele jego elementów przejęło wiosenne święto Panja przypominające zoroastryjskie Farvardegān. Por. E.S. Drower, The Mandeans of Iraq and Iran, Oxford 1937, s. 84-98. Jak zauważa Drower: „New Year's Day commemorates the Creation, for the Mana Rabba Kabira or Great Spirit, completed his work of creation on this day". Eadem, The Mandaean New Year Festival, „Man” 1936, nr 36, s. 186. 
też z tego względu Nowym Rokiem Anioła Pawia (Serêsalê Tawusî Malak) tudzież Świętem Anioła Pawia (Eide Tawusî Malak).

W kwietniu 2014, 2015 i 2018 r. miałem okazję mieszkać wśród Jezydów w Szejchanie i obserwować przebieg środowego święta zarówno w Lalisz, jak i w jezydzkich domostwach. Trwa ono, z naszej perspektywy, przez dwa dni: od wtorkowego wieczoru, do środowego zmierzchu. Przygotowania do niego rozpoczynają się we wtorek rano, kiedy krasi się jajka. Część skorupek, wraz z czerwonymi kwiatami, curry, gliną oraz wodą ze świętego źródła, posłuży do utworzenia szczególnej mieszaniny, którą przylepi się o świcie do nadproży drzwi, nad wejściem do domostw i świętych miejsc. Resztę skorupek rozrzuci się na polach, aby zbiory były obfite. Tego dnia odwiedza się też cmentarze i w muzycznej asyście kełłalów oddaje się cześć zmarłym. Po południu całe rodziny udają się do świętej doliny Lalisz, która jak wierzą, w toku kreacji świata zstąpiła z niebios na ziemię. Aby nie skalać tego miejsca, przed wkroczeniem do niej pielgrzymi zdejmują obuwie. Następnie odwiedzają licznie tu położone sanktuaria, często mieszczące się w grotach, z których każde ma własną specyfikę i wiąże się z osobnym rytuałem. Wchodzą też na święte wzgórze Arafat, wiążą supły na świętych drzewach, palą oleje w kapliczkach, a wreszcie nieprzerwanym korowodem schodzą w podziemia głównej świątyni, gdzie w mrocznej jaskini bije źródło Zem-zem ${ }^{44}$.

Przed rozpoczęciem święta część z mieszkających w dolinie kobiet piecze świąteczny chleb (sawuk), mężczyźni zabijają rytualnie zwierzęta. Trwają jeszcze porządki, a służebnicy świątynni (xilmetkar) sprzątają całą okolicę. Na głównym dziedzińcu, przed ozdobionym wielkim miedzianym wężem wejściem do mauzoleum Szejcha Adiego, zgromadzona jest cała jezydzka starszyzna pod przewodnictwem Baby Szejcha. Brodaty starzec spoczywa w cieniu, na kamiennym tronie. Pielgrzymi proszą go o błogosławieństwo, składają mu dary i krótko z nim rozmawiają. Słońce powoli kryje się za wzgórzami. Wówczas Baba Szejch podnosi się i intonuje modlitwę. Następnie wchodzi do sanktuarium, aby po chwili wyjść stamtąd w asyście duchownych, niosąc święty płomień. Wszyscy Jezydzi rozpalają od niego (a później od siebie nawzajem) przygotowane wcześniej knoty, które umieszczają na trzymanych w dłoniach kamykach i misach. Towarzyszący mu jezydzcy duchowni wychodzą na największy zewnętrzny dziedziniec, gdzie wśród setek płonących ogni (i błysków fleszy) witają ich wiwatujące tłumy. Ci, dla których nie starczyło miejsca, wspięli się na pagórki i dachy sanktuariów, skąd przez ciemność nocy przebija się blask migoczących płomieni. Rozlegają się okrzyki na cześć Anioła Pawia i Sułtana Jezyda (np. Hole hola Siltan Êzdî ye, hola Tawisî Melek e!), recytowane są hymny i słychać instrumenty kełłalów - flet (shebâb) i tamburyn (daff) ${ }^{45}$.

Większość pielgrzymów, którzy nie nocują na terenie świątynnym, powraca nocą do domów. Pozostali na miejscu będą natomiast rano świadkami chrztu

${ }^{44}$ Warto zauważyć, że dolina Lalisz wygląda na świadomą kopię Mekki, o czym świadczy tutejsza toponimia.

45 Ten ,zestaw” instrumentów ma starą tradycję, m.in. związaną z wiosennymi procesjami na cześć Baalszemina, podczas których grano na rogu i tamburynie. H.J.W. Drijvers, op. cit., s. 181. 
sandżaka - miedzianego statywu zwieńczonego podobizną Anioła Pawia ${ }^{46}$. Duchowieństwo rozkłada go wówczas na części i obmywa świętą wodą w wielkiej misie, aby był gotów do odbycia Parady Pawia (Tawûs gerran) - corocznego obyczaju obwożenia sandżaka po jezydzkich wioskach. O poranku, jeszcze przed wschodem słońca, umieszcza się na nadprożu głównego portalu świątynnego, obok miedzianego węża, zbitkę czerwonych kwiatów, curry, skorupek i gliny ${ }^{47}$.

Od rana Jezydzi składają sobie wizyty, nie wychodzą jednak poza najbliższe sąsiedztwo, uważają bowiem, że w środę nie należy podróżować. Obdarowują się prezentami i życzeniami i grają w hekkane (kurd. hêk, 'jajko'), grę znaną także polskiej wielkanocnej tradycji , polegającą na uderzaniu przez graczy pisanką o pisankę, tak aby stłuc skorupkę przeciwnika, a swoją ocalić. W grę tę grają wszyscy Jezydzi - od Baby Szejcha i fakirów do najmłodszych dzieci. Tego dnia śpiewa się też cytowany wcześniej Hymn Środy (Qewlê Çarşemê).

\section{5. Środa jako początek tego świata}

Dla dalszych rozważań pomocne będzie odwołanie się do al-Biruniego. Ten średniowieczny perski uczony, poza skrupulatnym katalogowaniem niezliczonych informacji na temat różnych kultur, opatruje je często wnikliwymi komentarzami filozoficznymi, które pozwalają na dostrzeżenie pod postacią zjawisk społecznych manifestującej się w nich idei. Swoje dzieło rozpoczyna od rozważań nad dniem, a ściślej nad dobą (,noco-dniem”). Zestawiając różne podejścia w jej rozumieniu, odnotowuje:

Arabowie za początek ich doby przyjmują moment, w którym zachodzące Słońce przecina krąg horyzontu. Toteż ich doba rozciąga się od chwili, kiedy Słońce znika pod widnokręgiem, aż po [jego kolejne - A.R.] zniknięcie nadchodzącego dnia. Do przyjęcia tego systemu skłonił Arabów fakt, że ich miesiące oparte są na biegu Księżyca i wynikają z jego nieregularnych poruszeń oraz że początki miesięcy ustalono nie w wyniku obliczeń, lecz na podstawie pojawiania się nowych faz Księżyca. Pełnia Księżyca, której pojawienie się jest dla Arabów początkiem miesiąca, staje się widoczna przy zachodzie Słońca. Toteż u nich noc poprzedza ich dzień; i tym samym mają oni w zwyczaju dawać nocom pierwszeństwo przed dniami, kiedy wspominają o nich w związku z nazwami siedmiu dni tygodnia ${ }^{48}$.

Słowa te opatruje następującym wyjaśnieniem:

Ci, którzy się w tym z nimi zgadzają, bronią tego systemu, mówiąc, że ciemność w porządku (tworzenia) poprzedza światło, oraz, że światło wyłoniło się nagle, kiedy istniała już ciemność; że, wobec tego to, co wcześniejsze w istnieniu, jest najwłaściwsze do przyjęcia jako początek.

46 Zob. P. Nicolaus, The Lost Sanjaq, „Iran and the Caucasus” 2008, nr 12, s. 217-251.

${ }^{47} \mathrm{Na}$ temat podobnych obyczajów piszą: hinduskiego - I. Joseph, Yezidi Texts (Continued), op. cit., przyp. 66, s. 253; i mandajskiego - E.S. Drower, The Mandaean New Year Festival, op. cit., s. 187.

48 Al-Biruni, The Chronology of Ancient Nations, op. cit., s. 5-6. Por. Koran XXXVI 37-40. Por. The History of al-Tabarī, Vol. 1, thum. F. Rosenthal, Albany 1989, s. 211-212, 228-249. 
Toteż uważają brak ruchu za lepszy od ruchu, porównując spoczynek i spokój z ciemnością, oraz z uwagi na fakt, że ruch jest zawsze wywołany przez jakiś brak i koniecznośćt9.

Al-Biruni zestawia ten system między innymi z bizantyjskim, w którym początek doby (jak również miesiąca) wyznaczany jest przez moment wschodu słońca. Także i tu dodaje metafizyczne uzasadnienie:

Toteż dla nich dzień poprzedza noc, za czym ich zdaniem przemawia to, że światło jest Bytem, a ciemność Nie-bytem. Ci, którzy myślą, że światło zaistniało przed ciemnością, uważają ruch za lepszy od spoczynku (braku ruchu), ponieważ ruch jest Bytem, a nie Nie-bytem - jest życiem, a nie śmiercią ${ }^{50}$.

Stosując proponowaną przez al-Biruniego egzegezę, należałoby powiedzieć, że Jezydzi należą do tradycji, która początek (zarówno doby, jak i świata) upatruje w ciemności i statyczności, z jakich wyłonić miał się byt i ruch. Istotnie ich kosmogonia, o czym pisałem wyżej, jak również rozumienie doby odpowiadają temu ujęciu. Jest to również ujęcie obecne w księdze Genesis, w której czytamy, że pośród ciemności i bezmiaru wód powstała światłość, a dzień jest tu definiowany jako „wieczór i poranek". Tradycja żydowska jest w tym wypadku niezwykle istotna, wiąże ona bowiem kosmogonię z numeracją dni, a ta, wraz z przypisywanym im znaczeniem, została przejęta przez część kultur Bliskiego Wschodu. Jeśli założyć, że środa jest dniem czwartym, to jej szczególne uświęcenie w jezydyzmie może się wiązać z tym, jakie znaczenie nadano ongiś temu dniowi w Torze:

Bóg zechciał [dosł. 'rzekł' - A.R.], aby były światła na sklepieniu nieba, żeby oddzielały dzień od nocy i by były wyznacznikami świąt, dni i lat. I aby stały się światłami na sklepieniu nieba, by oświetlać ziemię. I tak się stało. I uczynił Bóg dwa ogromne światła - większe światło, aby rządziło dniem, i mniejsze światło, aby rządziło nocą. I gwiazdy. Umieścił je Bóg na sklepieniu nieba, aby oświetlały ziemię, aby rządziły dniem i nocą i aby rozdzielały światło od ciemności. I wiedział Bóg, że [to] jest dobre. I był wieczór, i był poranek - czwarty dzien $(1,14-19)^{51}$.

Biblijni egzegeci zauważyli już dawno, że dzień czwarty jest nawiązaniem do pierwszego dnia kreacji (podobnie jak piąty do drugiego i szósty do trzeciego), kiedy to Bóg powiedział, aby powstało światło, a następnie oddzielił je od ciemności. Pozwala to na stwierdzenie, że dzień czwarty (środa) w porządku stworzenia jest nowym początkiem, czy powtórzeniem aktu stwarzania świata, ale na innym poziomie, kiedy to jedno abstrakcyjne światło przyjmuje konkretniejszy wymiar w postaci „dwóch ogromnych świateł" i „gwiazd”.

W tym kontekście trzeba odnotować, że na określenie Słońca, Księżyca oraz gwiazd Jezydzi posługują się enigmatycznym określeniem „trzy litery” (sê herfa), które obecne jest w ich najważniejszym kosmogonicznym hymnie Qewlê Zebûnî

49 Al-Biruni, The Chronology of Ancient Nations, op. cit., s. 6.

${ }^{50}$ Ibidem.

${ }^{51}$ Tora Pardes Lauder. Księga Pierwsza: Bereszit, S. Pecaric (oprac.), thum. S. Pecaric, E. Gordon, Kraków 2001, s. 10. 
Meksûr w części dotyczącej Abrahama (w. 45-47), który pierwotnie miał oddawać im cześćc ${ }^{52}$.

Bóg w procesie stwórczym coraz bardziej konkretyzuje swoje stworzenie, co dobrze widać właśnie na przykładzie opisów światła i ciemności. Najpierw pojawia się światło, o którym czytamy, że ,jest dobre” i „oddzielił Bóg światło od ciemności”53, następnie jego manifestacja staje się dzień i noc („Bóg nazwał światłość dniem, a ciemność nazwał nocą"), a jeszcze później - właśnie dnia czwartego - światło ukonkretnia się w światłach na sklepieniu niebiańskim, których zadaniem jest ,żeby oddzielały dzień od nocy”. Idąc za tekstem Koranu (XXI 33) można powiedzieć, że „On jest Tym, który stworzył noc i dzień i słońce i księżyc”.

Środa jest więc w pewnym sensie dla Jezydów zarazem dniem czwartym, jak i pierwszym. Dopiero od środy można właściwie mówić o ziemskiej dobie, bowiem tego dnia pojawiają się, jak należy przypuszczać, słońce i księżyc oraz gwiazdy. Zarazem środa jest też końcem jednego z etapów stworzenia, bardziej abstrakcyjnego, obejmującego trzy pierwsze dni. Dopiero czwartego dnia Bóg zaczyna nadawać konkretniejsze postaci swym ideom. W środę powstaje świat (czy forma świata), ten świat, który znamy, gdzie dniem i nocą rządzą słońce i księżyc, będące z kolei dla Jezydów manifestacją Boga i jego aniołów.

Owa stopniowalność tworzenia, czy jego konkretyzacja, ma swoją wyraźną paralelę w jezydzkiej kosmogonii, która rozpoczyna się od ciemności, a w niej ujawnia się świetlista Perła, która następnie zostaje rozbita. Jej resztki, przywodzące na myśl skorupki jajka rozbijanego w środowe święto Nowego Roku, zostają w micie powiązane są ze słońcem, księżycem i gwiazdami. Jak czytamy w jezydzkim apokryfie Meszefa Resz, Bóg polecił sobie przynieść dwa kawałki owej Perły: ,[...] jeden umieścił pod ziemią, drugi pozostał u bramy nieba. Następnie umieścił w nich Słońce i Księżyc, a z rozproszonych kawałków Białej Perły utworzył gwiazdy, które zawiesił na niebie jako ozdoby" 54 .

Noworoczna Środa byłaby więc dla Jezydów symbolicznym momentem przejścia od mrocznego stanu niecielesności i śmierci do materialności, życia i światła. Dlatego euforię związaną z odradzaniem się świata przyrody poprzedzają wspominki zmarłych i wizyty na cmentarzach. Noworoczna środa jest dniem powstania słońca i księżyca oraz gwiazd świecących jak cekiny na płaszczu nieba, lecz zarazem powołania czy zstąpienia aniołów, które są z nimi powiązane i manifestują się przez nie. Dnia czwartego światło rozprzestrzeniło się po świecie jak ognie, które zebrani na święcie Jezydzi odpalają jeden od drugiego. Przede wszystkim jednak noworoczna środa jest świętem przywódcy aniołów, Anioła Pawia, rozumianego jako światłonośny dawca życia czy dusza świata. Tego świata, nad którym czuwają słońce, księżyc i gwiazdy. Z tego też względu można ją uznać za archetyp samej środy - który realizuje się i ukonkretnia w poszczególnych środach każdego tygodnia. Każdej kolejnej

52 A. Rodziewicz, Jezydzkie hymny kosmogoniczne, op. cit., s. 217.

53 Por. uwagi al-Biruniego na temat jednej z sekt żydowskich obchodzących Nowy Rok w środę i od tego dnia liczącej dni, miesiące i cykl świąt, a uzasadniającej to powstaniem w środę słońca i księżyca. Idem, The Chronology of Ancient Nations, op. cit., s. 278.

54 I. Joseph, Yezidi Texts (Continued), op. cit., s. 222. 
środy upamiętnia się dzień objęcia przez niego rządów nad światem. Środa jest więc dniem pierwszym ziemskiego świata.

Jeśli proponowana interpretacja jest poprawna, to uznanie przez Jezydów środy za dzień święty świadczy nie tyle o ich odróżnianiu się od judeochrześcijańskiej tradycji, ile o jej ciekawej kontynuacji.

\section{Bibliografia}

Akbaş E., Êzdiyatî - 1 (waneyên olî ji bo zarokên êzdiyan), Bremen 2009.

Alias A.Kh., Wednesday in Ezidism Mythology, „Silavgehalalish” 2010, nr 7.

Aristowa T.F., Kurdy Zakawkazja (istoriko-etnograficzieskij oczierk), Moskwa 1966.

Badger G.P., The Nestorians and Their Rituals: With the Narrative of a Mission to Mesopotamia and Coordistan in 1842-1844, t. 1, London 1852.

Bell G.L., Amurath to Amurath, London 1911.

Al-Biruni, Chronologie orientalischer Völker von Albērūnī, Leipzig 1878.

Al-Biruni, The Chronology of Ancient Nations, London 1879.

Boyce M., A History of Zoroastrianism, t. 1, Leiden 1975.

Boyce M., A Persian Stronghold of Zoroastrianism, Oxford 1977.

Boyce M., Further on the Calendar of Zoroastrian Feasts, „Iran” 2005, nr 43, s. 1-38.

Boyce M., On the Calendar of Zoroastrian Feasts, „Bulletin of the School of Oriental and African Studies" 1970, nr 33, s. 513-539.

Brockelmann C., Das Neujahrsfest der Jezîdîs, „Zeitschrift der Deutschen Morgenländischen Gesellschaft" 1901, nr 55, s. 388-390.

Browski L.E., The Yezidees, or Devil-Worshippers, „The Popular Science Monthly” 1889, nr 34, s. $474-482$.

Celîl O., Celîl C., Zargotina K’urda, Kurdskij fol'klor, t. 2, Moskwa 1978.

Chani Ahmed [Axmed Xani], Mem û Zîn. Kriticeskiy tekst, perevod, predislovie i ukazateli M.B. Rudenko, Moskva 1962.

Darwesh S., The Ezidis New Year Feast (Sare Sal), „Slavgaha Lalish” 2009.

Dehxodā A., Loghatnāmeh, M. Mo'in, J. Shahidi (red.), t. 8, Tehran 1993-1994.

Drijvers H.J.W., Cults and Beliefs at Edessa, Leiden 1980.

Drower E.S., Peacock Angel: Being Some Account of Votaries of a Secret Cult and Their Sanctuaries, London 1941.

Drower E.S., The Mandaean New Year Festival, „Man” 1936, nr 36, s. 185-188.

Drower E.S., The Mandeans of Iraq and Iran, Oxford 1937.

Drower E.S., The Peacock Angel in the Spring, „Journal of the Royal Central Asian Society” 1940, nr 27, s. 391-403.

Fowler G., Three Years in Persia: With Travelling Adventures in Koordistan, t. 1, London 1841.

Frankfort H., A Tammuz Ritual in Kurdistan (?), „Iraq” 1934, nr 1, s. 137-145.

Furlani G., Le Feste dei Yezidi, „Wiener Zeitschrift für die Kunde des Morgenlandes” 1938, nr 45, s. 49-84.

Grant A., The Nestorians: Or, the Lost Tribes, London 1841.

Guest J.S., Survival among the Kurds: A History of the Yezidis, London-New York 1993.

Gündüz Ş., The Knowledge of Life: The Origins and Early History of the Mandaeans and Their Relation to the Sabians of the Qur'an and to the Harranians, Oxford 1994.

Heard W.B., Notes on the Yezidis, ,Journal of the Royal Anthropological Institute of Great Britain and Ireland" 1911, nr 41, s. 200-219.

Hjärpe J., The Holy Year of the Harranians, „Orientalia Suecana” 1974-1975, nr 23-24, s. 68-83. 
[Izaak z Bartelli], Monte Singar. Storia di un popolo ignoto, Samuele Giamil (red. i thum.), Rome 1900.

Al-Jabiri Kh.F., Stability and Social Change in Yezidi Society, nieopublikowana rozprawa doktorska, Oxford University 1981 [1982].

Joseph I., Devil Worship. The Sacred Books and Traditions of The Yezidiz, Boston 1919.

Joseph I., Yezidi Texts, „American Journal of Semitic Languages and Literatures” 1909, nr 25, s. 111-156.

Joseph I., Yezidi Texts (Continued), „American Journal of Semitic Languages and Literatures” 1909, nr 3, s. 218-254.

Karciew [Karcow] J.S., Zamietki o turieckich jezidach, „Zapiski Kawkazkowo otdiela Imperatorskowo Russkowo Geograficzeskowo obszczestwa" 1891, t. 13, z. 2, s. 235-263.

Kasheff M., Sa īì̄ Sīrjānī A.A., Čahāršanba-sūrī, [w:] Encyclopcedia Iranica, E. Yar-Shater (red.), t. IV, fasc. 6, London 1990, s. 630-634.

Krajewski L., Le culte de Satan: Les Yezidis, „Mercure de France” 1932, nr 826, s. 87-123.

Krasnowolska A., Some Key Figures of Iranian Calendar Mythology (Winter and Spring), Kraków 1998.

Massé H., Croyances et coutumes persanes, Paris 1938.

Mokri M., Les rites magiques dans les fêtes du „Dernier Mercredi de l'Année” en Iran, [w:] Mélanges d'orientalisme offerts à Henri Massé, Téhéran 1963, s. 288-302.

Al-Nadīm, The Fihrist (Kitāb al-Fihrist), B. Dodge (red. i thum.), New York 1970.

Nau Abbé F., Tfinkdji J., Recueil de textes et de documents sur les Yézidis, „Revue de L'Orient Chretien" 1915-1917, nr 10 (20), s. 142-200, 225-275.

Nicolaus P., The Lost Sanjaq, „Iran and the Caucasus” 2008, nr 12, s. 217-251.

Omarkhali Kh., Rezania K., Some Reflections on Concepts of Time in Yezidism, [w:] From Daēnā to Dîn. Religion, Kultur und Sprache in der iranischen Welt, Ch. Allison, A. Joisten-Pruschke, A. Wendtland (red.), Wiesbaden 2009, s. 337-352.

Parry O.H., Six Months in a Syrian Monastery, London 1895.

Perwerda Êzidyatî. Rêza Şeşê Seretaŷ̂, Pîr Xidir Silêman (red.), Duhok 2712 [2013].

Пирбари Д., Ajda Czarszama Sarsale, „Nowyj Wzgljjad” 2012, nr 8, s. 6.

Пирбари Д., Jezidskij prazdnik «Klocza sare sale», „Novyj Vzgljad”2012, nr 7, s. 7.

Пирбари Д., Nowyj god u jezidow, www.ezidipress.com/ru/2014/04/15/чаршама-сарсале/ [dostęp: 29.11.2019].

Pritchard J.B., Ancient Near Eastern Texts Relating to the Old Testament, Princeton 1969.

Rodziewicz A., And the Pearl Became an Egg: The Yezidi Red Wednesday and Its Cosmogonic Background, „Iran and the Caucasus” 2016, nr 20, s. 347-367.

Rodziewicz A., Jezydzkie hymny kosmogoniczne: „Hymn o Nieszczęsnym Rozbitku” (Qewlê Zebûnî Meksûr) i „Hymn o Be i A” (Qewlê Bê û Elîf), „Przegląd Orientalistyczny” 2018, nr 265-266, s. 207-222.

Rodziewicz A., Odrodzenie religii jezydzkiej w Gruzji? Rozmowy z Dimitrijem Pirbarim, głowa Duchowej Rady Jezydów w Gruzji, „Fritillaria Kurdica. Bulletin of Kurdish Studies” 2017, nr 16, s. 4-67.

Rodziewicz A., The Nation of the Sur: The Yezidi Identity between Modern and Ancient Myth, [w:] Rediscovering Kurdistan's Cultures and Identities: The Call of The Cricket, J. Bocheńska (red.), Cham 2018, s. 259-326.

Rodziewicz A., Milete min Êzîd. The Uniqueness of the Yezidi Concept of the Nation, „Securitologia" 2018, nr 1, s. 67-78.

Rudenko M.B., Novogodnie obrjadovyje prazdniestwa u kurdow, [w:] Fol'klor i etngtafija. Obrjady i obrjadowyj fol'klor, B.N. Putiłow (red.), Lieningrad 1974.

Salih Kh., The Yazidian Religion as a Religion of Canonizing the Elements of Nature, „Lalish” 2013, nr 38, s. 8-29. 
Southgate H., Narrative of a Tour through Armenia, Kurdistan, Persia, and Mesopotamia, t. 2, New York 1840 .

Al-Tabari, The History of al-Tabarī, Vol. 1, thum. F. Rosenthal, Albany 1989.

Tora Pardes Lauder. Księga Pierwsza: Bereszit, S. Pecaric (oprac.), thum. S. Pecaric, E. Gordon, Kraków 2001.

Turgut L., Ancient Rites and Old Religions in Kurdistan, Erfurt 2013.

Zêdo H., Wate û Sembolîya Rengan di Êzidîtîyê, Qamişlo 2017. 